\title{
Retirement Imperiled: The Case Of HELOCs ${ }^{1}$
}

William A. Dowling, (E-mail: William.Dowling@Savstate.edu), Savannah State University

Caitlin Dowling, Savannah Arts Academy

\begin{abstract}
There is no escape from the onslaught. Advertisements arrive in the post, in the e-mail inbox, through phone solicitations, internet pop-ups, and radio and television spots. One would think that mortgages (1 st mortgages, Reverse Mortgages ${ }^{2}$, and Home Equity Lines of Credit, HELOC, ${ }^{3}$ ) have never been as popular. The advertisements show consumers using equity from their homes to purchase second homes, do home improvements, take luxury vacations, and go on cruises, purchase new/used/antique cars, boats, motorcycles and other consumer items. The origin for this trend can be traced to the "Tax Reform of 1986." Pre "reform", mortgages were used to pay for houses only as interest on consumer loans was also a tax deductible item. Post 1986, the only tax deductible interest for consumers was that paid on a mortgage. Shortly thereafter, the use of $2^{\text {nd }}$ mortgages to pay for automobiles started and the scope of uses for home equity and instruments designed to tap it has expanded ever since. As is always the case, choices have consequences and the use of funds obtained through mortgages can have undesirable consequences, particularly on the resources available for retirement. Thus, this research will explore the changing view of debt on the part of US Consumers' and the impact of this increased level of debt on consumers' spending habits, home equity and retirement security.
\end{abstract}

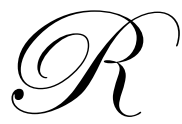

obert Samuelson wrote an article discussing changes in the personal savings rate of the American consumer. ${ }^{4}$ The personal savings rate has declined substantially since the "Tax Reform of 1986." 5 In 1984, the personal savings rate was at 10.8 percent. Since then it dropped to 4.6 percent in 1995 and to 1.8 percent in 2004. The data for 2005 reveals the rate declined to a negative $.4 \%$ and the annualized rate for the first half of 2006 was a negative $1.25 \%{ }^{6}$ The personal savings rate excludes the capital gains in stocks and housing. ${ }^{7}$ Some articles can be deceptive by including the capital gains therefore showing that the personal savings rate has actually risen, but indeed, it has not.

Even the popular press has expressed concern as evidenced by an article in the Savannah Morning News dated September 5, 2005 . According to the article, Americans' savings rate declined from 11 percent after World War II, to 1.8 percent before 2005, and it fell to 0 percent in the spring of 2005. Subsequently, the savings rate fell to a negative six-tenths of one percent ${ }^{9}$.

\footnotetext{
${ }^{1}$ This effort originated as my daughter's social science project. While assisting her efforts to define and research a topic, mutually we became interested in HELOCs and their potential impact on "Boomer's" retirement, thus, our joint effort.

${ }^{2}$ Explanatory note- Reverse Mortgage- A mortgage that allows you not to have to make payments until the house is sold.

${ }^{3}$ Explanatory note- HELOC- Home Equity Line of Credit- where the equity in the home serves as collateral for a line of credit.

${ }^{4}$ Robert. J. Samuelson from Newsweek MSNBC_2005

${ }^{5}$ Explanatory note- Personal Savings Rate- According to Samuelson the personal savings rate is Americans' total consumption spending from their total after tax income.

6 BEA News Release Gross Domestic Product - July 28, 2006 http://www.bea.gov/bea/newsrel/gdpnewsrelease.htm and http://www.bea.gov/bea/newsrelarchive/2006/gdp206a.xls - Tables 10 and 10(2)

7 Explanatory note - Capital Gain - A Capital Gain is a rise in value from the price it was when it was purchased to what it could be sold for in the present.

${ }^{8}$ Savannah Morning News article - 9/05/05

${ }^{9}$ ING Direct, page 2
} 
In 2000, household debt exceeded 18 percent of disposable income for the first time in 20 years. This means that 18 cents out of every dollar available to American families goes for interest on debt and debt repayment. The Savannah Morning News quoted Pat Frank and Mike Sievers, lead counselors of Consumer Credit Counseling Service of Savannah, as saying that over twenty five percent of their clients have car payments that exceed 600 to 700 dollars monthly, yet they cannot afford to put groceries on the table. In the same article, Felicia Brown was quoted, "We're led off on this belief that we should buy, buy, buy, but we're not saving anything." For the purposes of this paper, it is important to note that the authors of the newspaper article suggested that Americans have been substituting the soaring equity in their homes, caused by the rapid rise in housing prices, for traditional forms of savings. People are no longer putting their money into savings accounts. Instead, they are using their home equity as their savings. Additionally, they raised the question as to whether the housing boom (as evidenced by the rapidly appreciating price of housing) will continue or burst.

The "pseudo" savings comprised of stock and capital gains have indeed increased markedly. The stock capital gains from 1985-2005 increased from 1.3 trillion dollars to 10 trillion dollars (a geometric mean increase of 10.74 percent per annum). The real estate capital gains have increased from 4.6 trillion dollars in 1985 to 17.7 trillion dollars in 2005 (6.97 percent per year) ${ }^{10}$. According to Samuelson, the inclusion of capital gains in the definition of savings is the basis for the deception in showing a positive savings rate. Overall, Samuelson shows that Americans' savings have moved from a traditional fashion, such as voluntarily creating savings accounts, certificates of deposit, and other forms of savings, to a nontraditional, involuntary form known as capital gains.

Given the total increase in capital gains (stock and real estate) of 21.5 trillion dollars and using the midpoint of the multiplier range used by the Federal Reserve System, this increase in capital gains fueled an additional 860 billion dollars in consumption. ${ }^{11}$ The increase in consumption sparked by the increase in homeowner equity alone amounted to over 520 billion dollars.

Many have argued that the recent "bubble" is likely to burst soon as an increase in interest rates of two percent would result in a significant increase in the default rate and as a consequence many would be either homeless or almost homeless as a result of the loss of their home equity. For "boomers", one of the consequences will be a postponement of retirement.

Since the end of 2001 consumer debt has increased to a total level of 11.8 trillion dollars, this increase was no doubt encouraged by the existence of low interest rates. ${ }^{12}$ Interest rates that were historically low have allowed individuals(and lenders have actively encouraged individuals) to use home equity to fund both additional consumption (cars, clothes, vacations, etc.) and to retire existing revolving consumer debt that represents past deficit spending for consumption. Consumer credit balances have risen above 2.1 trillion dollars, about $\$ 9,710.69$ dollars per U.S. household. ${ }^{13}$ Of this, 800 billion dollars was in revolving credit card balances and this is incidentally, more than double the credit card debt in $1995 .^{14}$

Since 2001, consumers have originated mortgages amounting to 8.8 trillion dollars, an increase of 42 percent. The psychology is relatively easy to understand, as consumers note rapidly rising real estate prices and they feel richer as a result. Consequently, consumers increase day-to-day spending habits. ${ }^{15}$

\footnotetext{
${ }^{10}$ Total increase in capital gains per year was from 5.9 trillion to 27.7 trillion, 8 percent on an annual basis.

${ }^{11}$ Dynan, Karen. Johnson, Kathleen and Pence, Karen. "Recent Changes to a Measure of U.S. Household Debt Service" The Federal Reserve Bulletin, October 2003, http://www.federalreserve.gov/pubs/bulletin/2003/1003lead.pdf.

${ }_{12} \mathrm{http}: / /$ research.stlouisfed.org/fred2/series/CMDEBT/97/Max and http://research.stlouisfed.org/fred2/data/CMDEBT.txt

13 Perspectives on Recent Trends in Consumer Debt by Andrew Kish, a Discussion Paper of the Payment Cards Center, Federal Reserve Bank of Philadelphia, June 2006, http://www.phil.frb.org/pcc/D2006JuneConsumerDebtCover.pdf

${ }^{14}$ Note that this 800 billion doesn't include the 1.3 trillion in personal debt for cars, appliances, and personal items.

${ }^{15}$ Empirical Evidence on Household Wealth and Spending - At the aggregate level, the effect of wealth on consumption has been a mainstay of large-scale econometric models for at least thirty years. The econometric model of the U.S. economy used by the Federal Reserve has included a wealth effect for all this time, one that suggests that an additional dollar of household wealth leads, over time, to a permanent rise in household consumption of about three to five cents. Remarks by Governor Edward M. Gramlich before the International Bond Congress, London, U.K., February 20, 2002
} 
As consumer mortgage debt has risen so has its significance as a percent of total consumer debt. Chart 1 , (Figure 1 in the Appendix), shows that from 1970, when mortgage debt was only 63 percent of total debt to 2003, mortgage debt as a percent of consumer debt rose to 72 percent. ${ }^{16} 17$

Since 1986, household mortgage debt grew 151 percent while non-mortgage consumer debt grew only 88 percent. Further, since the end of 2000 , total mortgage debt grew 47 percent (2.25 trillion dollars). What this illustrates is that Americans are purchasing real estate in large numbers and/or are refinancing existing real estate with higher loan to value ratios. ${ }^{18}$ According to the Federal Deposit Insurance Corporation, 69.3 percent of families now own their own home (over 12 million new homeowner households in the last decade alone ${ }^{19}$ ).

Previously it was discussed that residential equity was increasingly the only form of consumer savings. However, according to the Federal Deposit Insurance Corporation, homeowner equity has grown concurrently with mortgage debt. Specifically, since 2000, total homeowner equity has increased 2.2 trillion dollars. This dichotomy is explained in a study released by Demos. ${ }^{20}$ According to this research, the average individual homeowner's equity fell from 68.3 percent of appraised value to 55 percent, during the period - 1973 to $2004 .^{21}$ Thus, while more Americans were indeed buying homes and concurrently, existing homes were increasing in value, the change in Americans' borrowing habits resulted in their owning less of their home than they did 30 years ago. Figure 4 (Figure 2 in the Appendix) illustrates this trend. ${ }^{22}$ According to the Demos article, since the Tax Reform of 1986, Americans have been using their homes as ATMs. American households have spent 333 billion dollars of equity using their house as collateral between 2001 and 2003. ${ }^{23}$ This increasing trend is illustrated in the exhibit titled Figure 1 (Figure 3 in the Appendix.) ${ }^{24}$ The amount of the equity reduction is three times higher than any other 3 -year period ever tracked. Interestingly, most of the households that were referenced between 2001 and 2003 used the cash equity from their houses to pay for living expenses and pay off credit card debt. Clearly the attitude towards consumer debt has changed.

One can see from the exhibit titled Figure 2 (Figure 4 in the Appendix), that half of the equity cashed out via the refinancing went to repayment of other debts. ${ }^{25}$ This is a clear example of the tendency of Americans to live beyond their means, where current living expenses are financed through long-term variable rate mortgages on their homes. Consequently, this results in a lessened cash value of their homes, which many American households depend on for economic security. As the Federal Reserve has continued to raise interest rates, households with adjustable rate mortgages are suffering with increases in their monthly payments. The obvious danger here is that higher mortgage payments require consumers to either spend more to cover the increased payment, an unlikely option given the negative rate of personal savings or reprioritize existing expenditures. This is a rapidly growing financial threat.

The extent of the threat can be illustrated by examining the 1996-97 time period. During this period, 5500 households per day used equity loans to pay off credit card balances that averaged 6,500 dollars. Further, a survey of over 6,000 households revealed that fully 70 percent of those who borrowed against their equity to retire credit

\footnotetext{
13 Ibid

${ }^{16}$ FDIC Winter Outlook 2004 p2

${ }^{17}$ Explanatory note- Tax Reform Act of 1986- The point of 1986 is referenced on the graph because of the Tax Reform Act of 1986. The Tax Reform Act of 1986 states that credit card interest and such is not tax deductible, only mortgage interest is tax deductible.

${ }^{18}$ Explanatory note - A Loan to Value Ratio- A loan to value ratio is the amount of money you have in a loan against your house versus how much the home is worth.

${ }^{19}$ FDIC Winter Outlook 2004 p2

${ }^{20}$ Javier Silva, "House of Cards" Demos , p5

${ }^{21}$ Ibid

${ }^{22}$ Silva , p5

${ }^{23}$ Silva ,Figure 1 p3

${ }^{24}$ Silva, Figure 1 p3

${ }^{25}$ Silva, Figure 2 p3
} 
card debt, had reacquired additional credit card debt free one year later (only 30 percent remained debt free). The average amount of new credit card debt was 2,133 dollars. $^{26}$

Further, 2000 to 2004, total household debt increased at an average annual growth rate of 11.81 percent. ${ }^{27}$ At the same time, total mortgage debt grew at a 13.6 percent annual growth rate. During the period, household mortgage debt increased from 4.4 trillion dollars to 7.5 trillion dollars, a 66 percent increase.

Additional evidence of changing attitudes towards debt is available from the fact that in 1999, credit card debt increased from 203 billion dollars to 453.6 billion dollars. ${ }^{28}$ Further, the average HELOC in 2003 was 69,500 dollars. ${ }^{29}$ Finally, consumer debt increased from 6.5 trillion dollars to 10.2 trillion dollars, an increase of 56 percent.

Clearly, households are digging themselves deeper into debt by deficit spending and then trying to pay it off with equity withdrawals from that available in their homes. It should be pointed out that this might not have as much of a negative effect if it were a one-time they didn't overspend again after they paid things off.

Ninety-seven percent of all homeowners have some equity. Typically, the average is 70,000 dollars, which is 42 percent of their total wealth (thus the average total wealth is approximately 163,000 dollars). ${ }^{30}$ The distribution of wealth however is not symmetric. For the lower economic class (lowest 20 percent of incomes) home equity is 80 percent of total wealth. For the next 20 percent of incomes, home equity is 60 percent of total wealth and for the uppermost 20 percent home equity is only 26 percent of total wealth (using a weighted average approach this implies that for the lowest 40 percent of incomes, home equity is 70 percent of their total wealth).

It has been shown previously, that families' equity, on average, is declining. This is because they are using HELOCs to pay for credit card debt and current living expenses. The implication of this is that as homeowners reach retirement age, that home equity, which traditionally served as a cushion, will no longer be available. A bursting of the housing bubble, with declining housing prices would further erode homeowner equity in the best case, or in the worst case homeowners would owe more than their house was worth.

The importance of a home equity cushion for families cannot be underestimated. Some experts think that you should have a 20 percent equity cushion $^{31}$ to cover emergencies or the bursting of the housing bubble.

Others recommend that homeowners avoid using HELOCs altogether. Their rationale is that it makes little economic sense to mismatch the maturity of assets and liabilities. That is, to use a HELOC to purchase an automobile uses long term debt( a second mortgage) to pay for an asset whose economic life is not as long as the maturity of the debt. Further, the expanding significance of reverse mortgages will enable retirees to enlarge their retirement incomes assuming, of course, that a significant equity cushion exists.) For example, in 2004 there were 37,839 reverse mortgages. That was more than double the number of reverse mortgages in 2003, and the 2005 figure was is excess of $60,000^{32}$.

Given the growth in HELOCs and declining homeowner equity, it is clear that a significant portion of the wealth of various social classes is at risk. For those in the lowest 40 percent of incomes, 70 percent of total wealth is in homeowner equity. If this is, spent to enable consumers to live beyond their means, then there is a significant probability for financial difficulties for this economic class. Of course, one must admit that there is the possibility that interest rates could stay low and housing prices could continue to rise. If this were to occur then all would be well. However, both the recent behavior of the Federal Reserve Open Market Committee and economic history are clear indicators that the probability of this happening is very unlikely.

\footnotetext{
${ }^{26}$ Michael Larson, Bankrate.com

${ }^{27}$ Bopnews.com, June 19, 2005

${ }^{28}$ Larson

${ }^{29}$ Larson

${ }^{30}$ Broderick Perkins, "Home Prime Source of Wealth For Some Groups", Realty Times

${ }^{31}$ Justin Martin, Money Magazine

${ }^{32}$ Peter Davidson, Bankrate.com, p1
} 
Ideally, homeowners should be very reluctant to withdraw equity from their homes. If they were going to use the equity, then one could make the case that it would be better spent by sending their children to college or for other worthwhile purposes (home repairs and customization). Unfortunately, the reality of the situation is that homeowners are using the equity from their homes to pay off their existing credit card debt. As earlier pointed out, this as a one-time event is not that bad but homeowners do not seem to be reducing their expenditures after paying off existing credit card debts. Consumption continues to exceed income.

As a result, as interest rates continue to escalate, more and more homeowners will find themselves with drastically reduced equity cushions or in some cases, the entire equity cushion will have been eliminated through deficit spending. The decrease in equity means that the principal amount of the mortgage has increased; raising the distinct possibility that many consumers will not be able to pay off their mortgage prior to retirement. Consequently, the cushion that home equity has previously provided for retirees will not available and based on the percentage of wealth that home equity comprises, a significant portion of the retiring population will have insufficient funds to cover both the remaining mortgage payments and living expenses. The next generation will not only have the deficit in Social Security to worry with; they will have an increasing number of retirees who will demand increasing levels of governmental support for basic subsistence. It is not difficulty to imagine an exacerbation of generational strife created by this increased burden of social expenditures. Future generations will find that their standard of living is reduced due to the deficit spending of their parents.

There is no easy solution to this problem and the alternatives are few. One approach is education. Increasingly, elementary, secondary and university level educators have altered curriculums to include the tenants of consumer finance. Further, the financial press has recognized the problem and has started sounding the alarm and as a result, newspapers columns, television segments and talk radio have begun to focus on this issue. While this is a positive step, it does little to deal with the current problem since those most significantly impacted (the lower $40 \%$ of income earners) are least likely to be impacted since as a group, fewer of them are consumers of these communication venues and most importantly, for this group, the damage is already done.

One straight forward approach would be an Internal Revenue ruling that reaffirmed the original intent of the second mortgage was that the funding was to be applied to real estate. Given the significance of HELOCs and their profitability for financial institutions, this is unlikely. Another approach would be the elimination of the tax deductibility of mortgage interest. The consequences of such an action on the housing segment and the resulting social unrest would not be pleasant.

In summary, current research indicates that Americans' view of debt and their resulting cashing out of equity has almost eliminated retirement security. Americans are all too often using the equity in their homes to fund a credit line. As the future generation approaches economic maturity, they will have a choice of either allowing a significant portion of the elderly population to exist below the poverty level or to pay more taxes; even though they will obviously receive less than the previous generations in social transfer payments. The current generation of "boomers" seems willing to bet that their children and their children's' children will be willing to forfeit their standard of living to pay for the behavior of the spendthrift families of the previous generations.

Unfortunately, there is no easy way to deal with the problem, yet something clearly has to be done. The best case scenario would be to have the best of all possible worlds with stable interest rates, housing prices and levels of economic activity. If history is a guide, the likelihood of this is slim and the next generation will indeed find themselves be asking themselves the question, "Why should we pay for the unwise decisions of our parents?" 
Appendix

Figure $1^{33}$

\section{Mortgage Debt Has Risen as a Percentage of Total Household Debt, Particularly Since the Tax Reform Act of 1986}

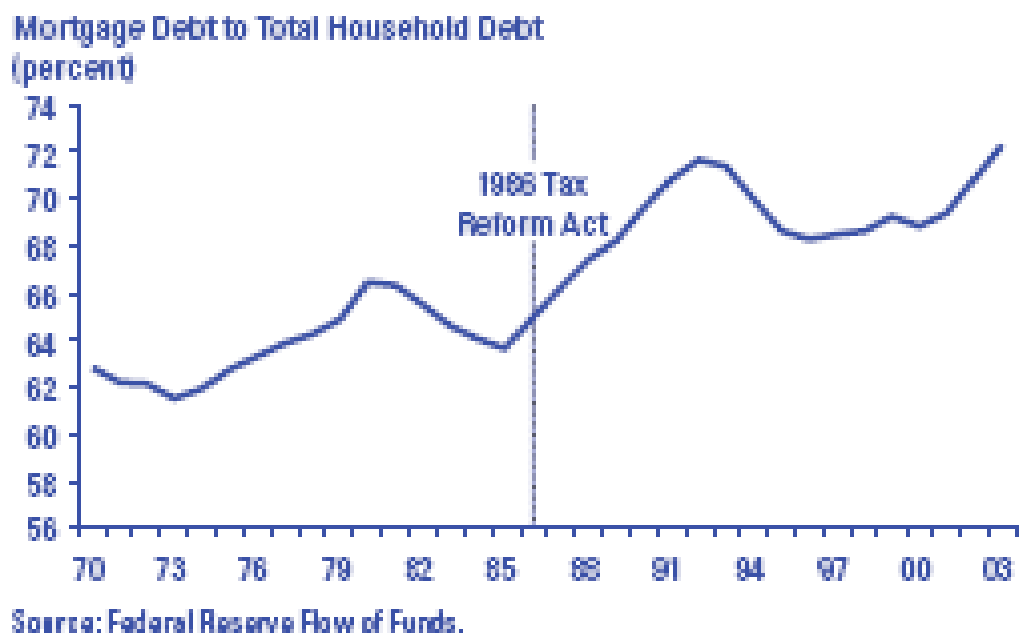

Figure $2^{34}$

Figure 4. Homeowner Equity as a Percentage of Household Estate and Homeownership Rates, 1973-2004

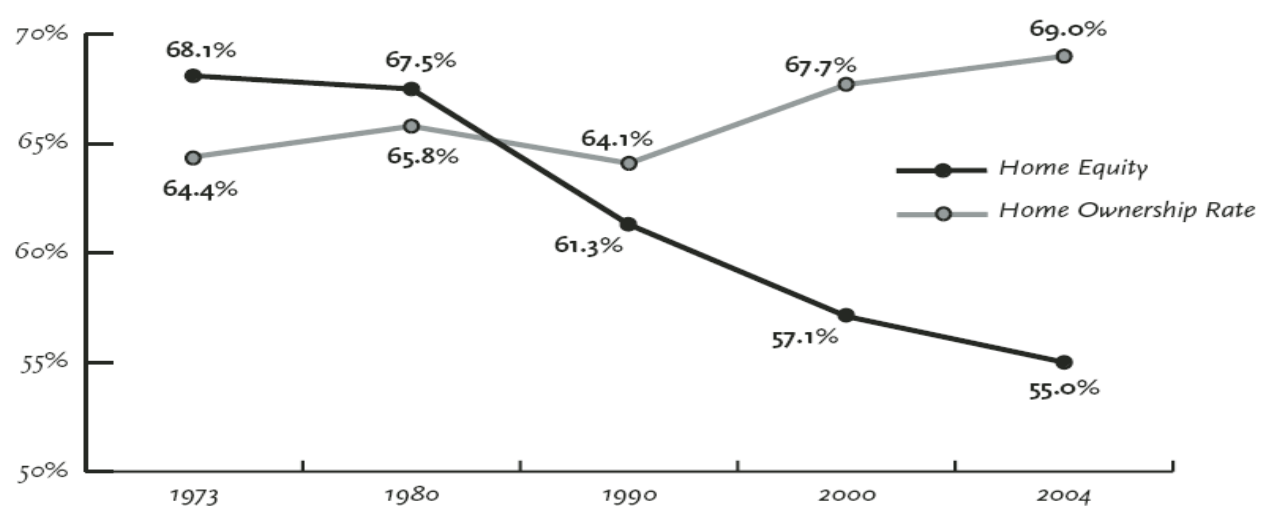

Source: Federal Reserve System, Flow of Funds Accounts of the United States and US Census Bureau.

${ }^{33}$ FDIC Winter Outlook 2004 p2

${ }^{34}$ Silva, p5 
Figure $3^{35}$

Figure 1. Amount of Equity Cashed Out Between 2001 and 2003 (in Billions of Dollars)

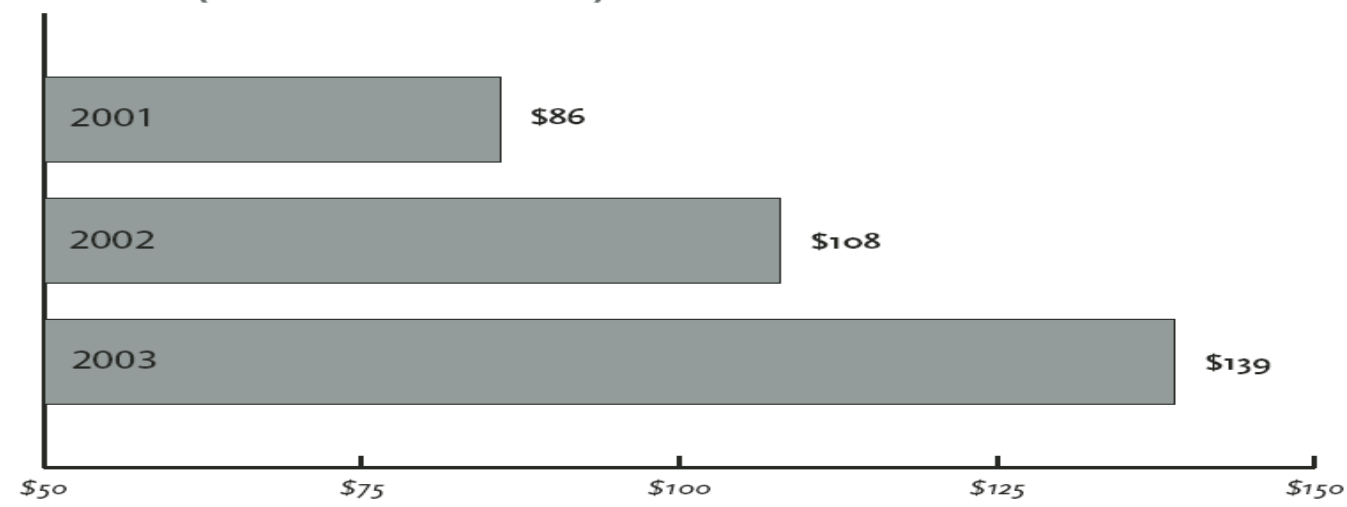

Source: Joint Center for Housing Studies of Harvard University.

Figure $4^{36}$

Figure 2. Use of Funds From Refinancings, 2001 and 2002

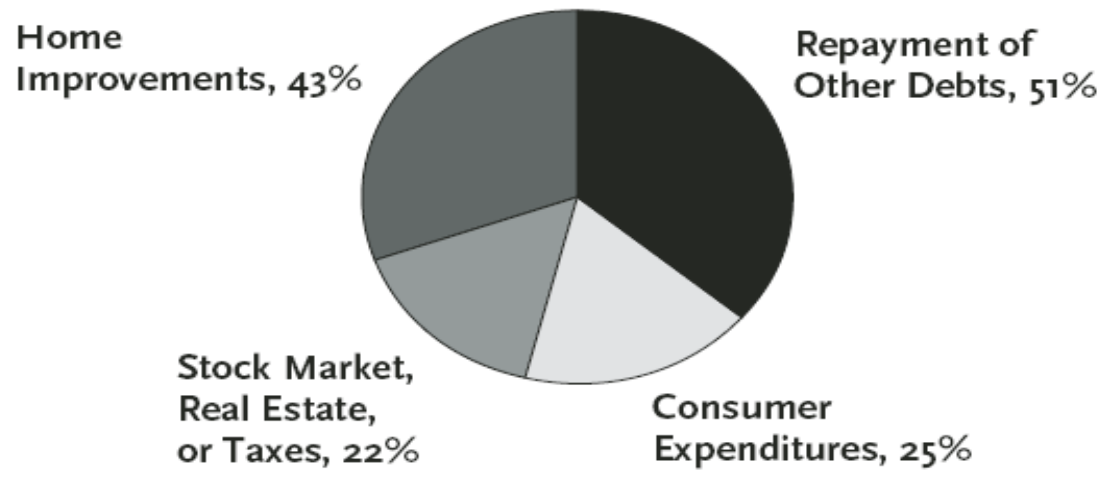

Percentages add up to more than 100 because each refinancing loan could have been used for multiple purposes. Source: Federal Reserve System, Flow of Funds Accounts of the United States.

${ }_{36}^{35}$ Silva Figure $1 \mathrm{p} 3$

${ }^{36}$ Silva Figure 2 p3 


\section{BIBLIOGRAPHY}

1. Angell, Cynthia. FDIC Outlook, In Focus this Quarter: The U.S. Consumer Sector, Home Equity Lending: Growth and Innovation Alter the Risk Profile FDIC Outlook Winter 2004, winter 2004,http://www.fdic.gov/bank/analytical/regional/ro20044q/na/2004winter_03.html.

2. $\quad$ Bright Spots. ING Direct. St. Cloud, Minnesota: ING Direct, October, 2005.

3. Davidson, Peter. Reverse Mortgages: Retirement's on the House Bankrate.com, May 23, 2005, http://www.bankrate.com/brm/news/mortgages/20050523a1.asp.

4. Dynan, Karen. Johnson, Kathleen and Pence, Karen. Recent Changes to a Measure of U.S. Household Debt Service The Federal Reserve Bulletin, October 2003, http://www.federalreserve.gov/pubs/bulletin/2003/1003lead.pdf.

5. Go easy on Home Equity Debt, Caution Planners The Financial Planning Association, http://www.fpanet.org/public/tools/articles/FPP0204/cfm.

6. Hacker, Diana. A Pocket Style Manual. Boston Massachusetts: Bedfords/ St.Martin's, 2000.

7. Hood, James. High Foreclosure Rates the dark Side of a Hot Real Estate Market ConsumerAffairs.com, June 8, 2005, http://www.consumeraffiars.com/new04/ 2005/foreclosures.html.

8. Household Debt Service and Financial Obligations Ratios Bopnews.com, June 19, 2005, http://bigpicture.typepad.com/comments/2005/06/houeshold_debt_html.

9. Larson, Michael. On Dangerous Ground- Many Use Equity Loans to Increase Debt Instead of Paying it Down Bankrate.com, September 1, 1999, http://www.bankrate.com/brm/ news/loan/19990901.asp.

10. Martin, Justin. Home Loan that's Easy to Carry. Or not Money Magazine. August 25, 2005, http://money.cnn.com/2005/08/18/real_estate/HELOCS_0509/.

11. Max, Sarah. Avoid the Home Equity Hangover CNNMoney, December 17, 2003, http://money.cnn.com/2003/12/11/pf/yourhome/home_equity_hangover/.

12. Perkins, Broderick. Home Prime Source of Wealth for Some Groups RealtyTimes.com, December 19, 2003, http://realtytimes.com/rtcpages/20031219_wealth.html.

13. Powell, Eilenn. Rising Debt: Americans Vulnerable to Rising Rates, Foreign Currency Imbalances. Savannah Morning News, Tuesday, September 6, 2005, Section A, Page 1.

14. Samuelson, Robert. Our Vanishing Savings Rate MSNBC Newsweek Business, 2005, http://www.msnbc.msn.com/id/8938151/site/newsweek/page/2/.

15. Silva, Javier. A House Of Cards: Refinancing the American Dream Demos.com, January, 2005, http://www.demos.org/pubs/ahouseofcards.pdf.

16. Tanner, Robert. Headed for a Crash. Savannah Morning News, Monday, September 5, 2005, Section A, Page 1.

17. Weston, Liz. Risky Home Loans Allow People with Poor Credit to Buy a House or More House Than They Can Afford, Realestate.msn.com/loans/Articles.aspx? $\mathrm{cp} /$ documented= 26584\&GT1=6974. 